\title{
THE EFFECT OF JOURNAL WRITING TECHNIQUE ON STUDENTS' WRITING ABILITY
}

\author{
Eliwarti $^{1}$, Indah Tri Purwanti ${ }^{2}$ \\ ${ }^{1,2}$ Faculty of Teachers Training and Education, Universitas Riau
}

Corresponding author: elieliwarti@gmail.com

\begin{tabular}{ll}
\hline \multicolumn{1}{c}{ Article Info } & Abstract \\
\hline $\begin{array}{l}\text { Received: 05 October 2021 } \\
\text { Accepted: 24 October 2021 } \\
\text { Published: 26 October 2021 }\end{array}$ & $\begin{array}{l}\text { This quasi-experimental research aims at looking at the effect } \\
\text { of Journal Writing technique on the ability in writing a } \\
\text { paragraph. Specifically, the research answers the research } \\
\text { questions about the students' ability in writing, the effect of }\end{array}$ \\
\hline Journal Writing technique on the students' ability in writing, \\
and the students' attitude toward Journal Writing technique \\
applied in their Writing class. The sample are one class from \\
the second semester of English Department students in 2017- \\
effect; journal writing \\
technique; writing ability \\
tests and the distribution of a set of questionnaires. From the \\
results, nearly 60\% of students' ability in writing is at Average \\
to Good level before the treatment. After the treatment, \\
56.76\% of their ability is at Good to Excellent level. To test \\
whether the increased score is statistically significant or not, \\
the data were analyzed using t-test. Having t-obs (8.26) which \\
is higher than t-table (2.030), there is a plausible reason to \\
believe that the teaching of writing using Journal Writing \\
technique significantly affects the students' ability in writing \\
paragraph. The data from questionnaire showed nearly 64\% \\
students have 'high' attitude toward Journal Writing technique \\
applied in their class.
\end{tabular}

\section{INTRODUCTION}

English Study Program offers several language skill courses to students, and Writing skill is one of the subjects offered. There are three writing skill courses altogether consisting of Writing Skill 1, 2 and 3. In this course, students are taught good writing techniques ranging from simple sentences, paragraphs, to various types of essays. As writing skills course is an application of other courses such as Structure, Vocabulary, Reading, etc., it cannot be denied that the course has high level of difficulty. This may be true as at the time of writing, the students need to think of the idea, use good grammar and use appropriate vocabulary. Even since last year, Writing Skill courses

\section{International Journal of Educational Best Practices (IJEBP)}


have been merged with Reading Skill courses under the name Pre-Intermediate, Intermediate and Post-Intermediate Reading and Writing courses.

Despite the complexity of writing skills, it is true to some extent that the students' low ability in writing might also be caused by the inappropriate teaching method used by the lecturers and lack of writing practice. Al-Khasawneh (2009) claims that the low writing ability of students are caused by several factors, including (1) the complexity of the language which includes vocabulary, idea organization, grammar, spelling, and references, (2) environment (culture) so that there is a lack of opportunity to practice, (3) teaching methods, low teaching abilities and lack of training. Therefore, students really need to be taught using appropriate teaching methods applied by experienced lecturers and to have more practice to develop their writing skills.

In addition, the ideas proposed by Al-Khasawneh (2009) are also in line with the results of a survey conducted by Eliwarti and Rumiri (2018) about learning writing in senior high schools in Riau Province as follows:

a. Riau province senior high school English teachers are oriented towards product approach,

b. Learning materials are dominated by grammar, word meaning and punctuation, which are the hallmarks of the Product approach

c. Students' attitude towards learning writing is in 'medium' level.

In the teaching and learning process, the main focus is on the learning process carried out by the students, not only the teaching process conducted by lecturers. This means that students are subjects in every educational process. Meanwhile, the lecturer acts as a mentor and at the same time as a facilitator. Relevant learning between lecturers as teachers and students as learners is a process that can make students actively involved in carrying out learning activities that support learning. According to Mel Silberman (2002), "during active learning activities, students do most of the work that must be done. They use their minds to learn, solve problems and apply what they learn. This principle needs to be applied in every learning process, including in the Writing course.

There have been many researches conducted so far by scholars about the application of journal writing, among them are a study by Barjesteh, Vaseghi and Gholami (2011) which investigates the effect of diary writing on EFL college students' writing progress and attitudes; the next study by Liao and Wong's (2001) which analyses the effectiveness of English dialogue journal writing on students 'writing fluency, reflections, anxiety, and intrinsic motivation, as well as the students' reaction to journal writing. The study by Mllynarczyk`s, 1998 (cited in Bagheri, Somayeh and Pourgharib, Behzad. 2013) focussed on dialogue journal writing using diary to develop language literacy; then Payton's study (2000) also focussed on using dialogue journal writing to develop language and literacy. Furthermore, Alexander's study (2005) investigates whether dialogue journal writing can enhance language fluency of adult students and

\section{International Journal of Educational Best Practices (IJEBP)}


helps them develop their vocabulary and grammar. This research focuses on the use of journal writing in college students, and the purpose of this study was to determine the effect of the 'Journal Writing' technique on their writing ability.

\section{Writing skills}

Writing skills are included in productive skills where the product of writing is the target in learning (Syameducation, 2011). Writing skills are crucial to teach as it is a device to convey thoughts to readers with a detailed purpose. As one of the language skills, writing skills are a very vital ways to communicate ideas. Even for a scientist or one in a writing-related job, this is sometimes an unavoidable demand. However, because of the complication of the writing process to produce a single piece of writing, writing skills are deemed difficult (Demirel, 2011; Raimes, 1983; Wiratno, 2003: 3). Ghaith (2002) also explains that writing as a complex process that permits writers to explore ideas. So, writing is a thoughtful process which comprises some stages and large period of time to state the writers' intention. In the process of writing, a writer desires to consider about many factors such as content of the writing, word choice, reader and grammar.

Murcia (2000) clarifies that writing is the creation of printed words in the structure of texts; therefore, it must be understood so that interaction takes place. English lecturers need to understand that writing is a complicated process because a writer has to consider not only the content, but also the reader that will read his writing. One will have to express his idea by considering who will read and how they will receive and understand his message through it. Oshima (1998) claims that whenever someone writes, he has to think about who will read his writing. The students majoring in English education are undoubtedly expected to be able to communicate through their writing. Murcia (2000) argues that writing becomes difficult because it needs a high level of creative language control compared to other skills. This makes teachers ought to be really creative in teaching writing.

Writing is considered to be a difficult skill. Difficulties might be caused by ignorance of (1) the problem to write about, (2) objectives to write, (3) how to express ideas, (4) the use of grammatical forms required by the writing, as well as (5) appropriate vocabulary to use (Wiratno, 2003:3). As a consequence, a student is actually able to write even with simple abilities, as long as he knows the aim of writing and able to convey the goal with the appropriate linguistic characteristics. The writing goal is the same as the social function of the text. While difficulties in vocabulary are able to be solved using a dictionary.

The purpose of writing is actually to direct thoughts or convey ideas; thus, these thoughts are considered to be as the most significant aspect of writing. Writers should focus on the writing aspects such as correct spelling and punctuation, acceptable grammar and correct vocabulary (Ur, 1996). Thus, it is quite clear that

\section{International Journal of Educational Best Practices (IJEBP)}

Vol. 5 No. 2 October 2021

ISSN: $2581-0847$

DOI: DOI: 10.32851/ijebp.v5n2.p183-196 
when the writer expresses his idea, he must be able to express it with correct grammar, choose the right words, and use accurate spelling and punctuation.

Lastly, we see what was stated by Oshima and Ann (1999:3) who explain that writing skills, especially academic writing, are not simple, both for native speakers and new English learners. Writing skill is a process, not a product, which requires review, revision, review, and revision again, so it can be said that it is never complete. Langan (2001) also argues that writing is a process of continuing discovery that comprises a sequence of stages, not an unconscious procedure. The writing process needs to be known and trained for students so that they can produce good writing both in terms of content and organization as well as mechanics, vocabulary and grammar.

The above opinion is in line with what is proposed by Raimes (1983). He says that constructing a piece of writing is not a simple skill but a complicated skill that drives writers to concurrently think about several factors such as ideas, choice of word, the reader and sentence structure. Demirel (2011) also says that writing skills are multiple skills that include many elements that must be solved simultaneously. Thus, it is true that writing is a multifaceted skill and a very difficult activity to do.

\section{Journal writing}

Journal writing is not the same as a diary journal. Journal writing unites thoughts and emotions while diary journal only writes our experience in our lives (Snyde \& Lidquist, 2010). Tarigan (2008:37) also explains that journals are given to others to be read while diaries are only kept as privacy. From the two definitions, it is quite clear that the purpose of writing the two journals is very different. The purpose of writing a diary journal is only to rewrite what has been experienced in life and only for personal consumption, while journal writing in the writing process does not only rewrite but also involves thoughts and emotions which is of course accompanied by analysis and evaluation. Because journal writing is for public consumption, the author is more careful in both ideas and language use. Furthermore, Castellanos (2008) explains that what is good about journal writing is the writer practices using vocabulary and grammar skills contextually. Thus, through journal writing the writer communicates and shares knowledge with others.

There are several types and formats of journal writing that have been developed. Hiemstra (2001) describes several types of journals writing. These include: 1). Learning Journals: Learning Journals are recordings during learning to increase the frequency of writing by providing stimulus when reading material or talking with friends. Stimulation can be from topics, articles, or singing; 2) Diaries: Diaries consist of daily experiences that include the chronology of events in a person's life; 3). Dream Book or Log: This is used for personal reasons in taping and inferring the dreams; 4). Autobiographies, Life Stories: Autobiography focuses on self-evaluation; life stories review the lives of others but can be used personally; and biographies

\section{International Journal of Educational Best Practices (IJEBP)}


have an informal approach in telling life stories; 5). Spiritual Journals: Spiritual journals are usually a bit different from regular journals. Spiritual Journals consists of recording an individual or spiritual responses to religious issues; 6). Professional Journals: Professional journals are part of the student's expert collection, and the material is distributed and criticized both by himself and by his fellow seminar participants; 7). Interactive Reading Log: This is a system for students to analytically exhibit on material; 8). Theory Log: A theory Log is critical reading of theory (Brookfield (1995) cited by by Hiemstra (2001); 9). Electronic Journal: This is a form of journal written on electronic media such as computers, etc.

From these types of journals, this research applies Learning Journal, which is a recording of the learning process that serves to increase the frequency and quality of writing. This is done by providing stimulation during discussions with friends in brainstorming activities and also during writing activities. Stimulation can be from topics, articles, experiences, and others.

\section{Benefits of journal writing}

Journal writing has been used as an efficient way to increase some skills of writing. The early study about Journal writing was conducted by Progoff et al.,(1997). They found that through journal writing, students voice opinions via writing and societal talents. The writers do not need to think whether what they write is correct or not. In the class, the teacher plays a role as a initiator (Krashen, 1998). Furthermore, Boud (2001) found that journal writing is a complicated action spent for various aims to stimulate thinking. Dissimilar approaches are able to be applied in diverse phases of learning.

Lewis (2009) explains that lecturers can use good topics, classical music and others so that students' writing is good and maximal. Lecturers help students achieve learning objectives by providing themes to write about. These themes are significant as they are able to assist students focus on writing. Furthermore, he says that journal writing is a good site to investigate for we can start forming ideas that we might initially hesitate to expose. Thus, it is believed that by continuing to write journals, students are able to work with words, rhythm, symbol, stability and conscience. Journal writing also helps develop a personal character that is very valuable for the author's self-control and emphasis (Crosby and Carter: 1986). 


\section{METHODS}

This quasi-experimental research was conducted in English study program of FKIP UR in even semester, 2017-2018 academic year. The population were all second semester students taking the Writing Skills I course (Writing I). They were 117 students comprising of four classes: class A - class D. The Cluster Random Sampling technique was used to determine the sample of this study. From the four classes, one class was taken to be the sample of this study.

There are two data in this study, the first is from the results of writing skills tests given to students. The second is nominal data from the questionnaire to find out how students' attitudes towards the 'Journal Writing' technique applied in learning writing. This research was conducted in 8 meetings. Pre-test is given before the action is taken. At each meeting, students get learning about journal writing and then write journal writing with several topics offered related to the learning topics at each meeting. The post test is given after the 8 meetings are finished. Then, the data was processed and analyzed by t-test while the data about students' attitudes were analyzed using SPSS.

The first data was obtained from the students' writing skills taken from the writing test. The test form is 'free writing' by asking students to choose one topic from several topics provided. From the chosen topic, students are asked to write a paragraph that is 10-15 sentences long. In order for the test results to be valid and reliable, students' writing was assessed by three raters. Aspects assessed in the writing skill test are: Organization, Structure, Vocabulary, Fluency and Mechanics.

The second data was collected through a questionnaire regarding students' attitudes towards 'Journal Writing' which was applied in learning of the Writing I course. The questionnaire contained statements about 'Journal Writing' and its benefits on their writing skills. Questionnaire items are made and refer to related investigation about writing skills. The contents of the items were acquired based on reading about the Journal Writing technique and its benefits on their writing skills. The questionnaire consists of two parts. The first part is about the demographic information of the sample such as name, gender. The second part is about the technique its benefits.

The contents of the questionnaire were validated by one expert from the English Education Study Program who had a doctoral education and had more than 20 years of teaching experience. Expert comments and suggestions were used to improve the questionnaire/instrument. The expert was given one copy of the questionnaire and one copy of the questionnaire validation checklist which contained a description of the item variables. The questionnaire was prepared in English and Indonesian, so the sample had the same understanding of each statement in the questionnaire. 
The Likert scale used in this study covers info approximately the statement of confirmity and regularity with which an activity is carried out. The scale for expressing agreement is Strongly Agree (SA), Agree (A), Uncertain (U), Disagree (D) and Strongly Disagree (SD); while the scale for expressing the level of frequency of an activity being carried out is Always (Al), Often (Of), Sometimes (ST), Rarely (Ra) and Never (Nv) (Setiyadi 2006).

Pallant (2001) explains that one of the most widely used internal consistency indicators is the Cronbach Alpha coefficient. Pallant (2001) recommends that the Cronbach alpha coefficient should be 0.70 and above to specify that the instrument used is reliable. This research refers to what was stated by Pallant (2001).

The writing ability test in which subjects are requested to select one of the topics offered is assessed using the "Analytical Scoring System" (Samad, 2004:43-44). There are five aspects that are assessed, each with a different weight according to the level of importance and emphasis. The five aspects are as follows:

Table 1. Aspects of Writing Assesment

\begin{tabular}{ll}
\hline Component & Weight \\
\hline Content & 30 points \\
Organization & 20 points \\
Vocabulary & 20 points \\
Language Use & 25 points \\
Mechanics & 5 points \\
\hline
\end{tabular}

In order for this writing ability test to be valid and reliable, this test is assessed by three raters. The calculations of the writing ability test were analyzed and the students' ability levels were interpreted using a table adapted from Haris (1974:134) as follows:

Table 2. Skill Level

\begin{tabular}{ll}
\hline Score & Ability Level \\
\hline $80-100$ & Good to excellent \\
$60-79$ & Avarage to good \\
$50-59$ & Poor to avarage \\
$0-49$ & Poor \\
\hline
\end{tabular}

Furthermore, to find out whether the technique of Journal Writing had a significant influence on students' writing skills, the writing ability data were statistically tested using a t-test. The t-test was used to find the difference in the mean concerning the results of the pre-test and the results of the post-test, (Hatch and Lazaraton, 1991). The data were tested with a significant level of 0.5 . 


\section{FINDINGS AND DISCUSSION}

\section{Findings}

The data in this study comprises two types. The first is the ability of students to write paragraphs afore and following the application of Journal Writing technique in learning writing skills. Furthermore, the second data is the student's attitude towards learning with the 'Journal Writing' technique.

\section{Students' writing skills}

Research question number 1 is how the writing ability of the students is. To answer this question, the pre-test was conducted at the seventh meeting to determine their ability before the learning by applying Journal Writing technique was applied. The students' ability to write paragraphs on the pre-test are presented in Table 2.

Table 3. Paragraph Writing Ability Pretest Score

\begin{tabular}{clcc}
\hline Score & Ability Level & Frequency & Percentage \\
\hline $81-100$ & Good to excellent & 11 & $29.73 \%$ \\
$61-80$ & Average to good & 22 & $59.46 \%$ \\
$51-60$ & Poor to average & 4 & $10.81 \%$ \\
$0-50$ & Poor & 0 & $0 \%$ \\
& Total & 37 & $100 \%$ \\
\hline
\end{tabular}

Almost $60 \%$ of students' paragraph writing skills are at the Average to Good level, more than $10 \%$ of students are at the Poor to Average level and the remaining almost $30 \%$ are at the Good to Excellent level. Based on the data above, the average score of students on the pre-test was 65.76 .

After being given teaching treatment by applying Journal Writing technique in Writing I learning for 8 meetings, the sample was given a posttest. The purpose of the posttest was to know if there was a significant difference in the mean between students' writing skills on the pretest and on the posttest. The level of students' paragraph writing skills on the posttest can be seen in Table 3 below.

Table 4. Paragraph Writing Ability Posttest Grade

\begin{tabular}{clcc}
\hline Score & Ability Level & Frequency & Percentage \\
\hline $81-100$ & Good to excellent & 21 & 56.76 \\
$61-70$ & Average to good & 16 & 43.24 \\
$51-60$ & Poor to average & 0 & 0 \\
$0-50$ & Poor & 0 & 0 \\
& Total & 37 & 100 \\
\hline
\end{tabular}


The data show that the majority of students' ability to write paragraphs is at the Good to Excellent level, which is 21 people or $56.76 \%$. The remaining $42.24 \%$ are at the Average to Good level and no student is at the Poor to Average level. The average score of students on the posttest was 80.46 .

From the pretest and posttest scores, research question 1 has been answered, namely almost $60 \%$ of the writing ability of the students before treatment was at the Average to Good level. Furthermore, 56.76\% of the writing ability of second semester students of the English Education Study Program FKIP UNRI after treatment was at the Good to Excellent level.

\section{The effect of journal writing technique on students' writing ability.}

The answer to research question number 2, the effect of the 'Journal Writing' technique on the students' writing ability was obtained from the analysis of students' posttest scores. The following is a comparison of student scores in writing paragraphs before and after the treatment was carried out.

Table 5. Pretest and Posttest Scores of Paragraph Writing Ability

\begin{tabular}{clcccc}
\hline \multirow{2}{*}{ Score } & $\begin{array}{l}\text { Ability } \\
\text { Level }\end{array}$ & \multicolumn{2}{c}{ Pretest } & \multicolumn{2}{c}{ Posttest } \\
\cline { 2 - 6 } & Frequency & Percentage & Frequency & Percentage \\
\hline $81-100$ & $\begin{array}{l}\text { Good to } \\
\text { Excellent }\end{array}$ & 11 & $29.73 \%$ & 21 & $56.76 \%$ \\
$61-70$ & $\begin{array}{l}\text { Average } \\
\text { to Good }\end{array}$ & 22 & $59.46 \%$ & 16 & $43.24 \%$ \\
$51-60$ & $\begin{array}{l}\text { Poor to } \\
\text { Average }\end{array}$ & 4 & $10.81 \%$ & 0 & $0 \%$ \\
$0-50$ & $\begin{array}{l}\text { Poor } \\
\text { Total }\end{array}$ & 0 & $0 \%$ & 0 & $0 \%$ \\
\hline
\end{tabular}

The score in the table shows a significant rise in the ability to write paragraphs prior to and following the treatment. The biggest increase was at the Good to Excellent level, which was almost $100 \%$; from 11 people $(29.73 \%)$ in the pretest to 21 people $(56.76 \%)$ at the posttest. Then there are no more students who are at the Poor to Average level. To test if the increase in the pretest to posttest scores was statistically significant, the data were analyzed using t-test. From pretest and posttest score data, the following values were obtained: 
Table 6. Result of t-test

\begin{tabular}{cccccc}
\hline \multicolumn{2}{c}{ Mean } & $\begin{array}{c}\text { Standard } \\
\text { Deviation }\end{array}$ & $\begin{array}{c}\text { Standard } \\
\text { Error }\end{array}$ & $\begin{array}{c}\text { t- } \\
\text { obs }\end{array}$ & $\begin{array}{c}\text { t- } \\
\text { table }\end{array}$ \\
\hline Pretest & Posttest & & & & \\
\hline 65.76 & 80.46 & 10.813 & 1.78 & 8.26 & 2.030 \\
\hline
\end{tabular}

With the value of t-obs (8.26) which is much greater than the value in the table (2.030) it can be said that learning Writing with Journal Writing technique affects students' paragraph writing skills. Thus, research question number 2 has also been answered, namely the Journal Writing technique has a significant effect on the students' ability in writing paragraphs.

\section{Students' Attitudes towards Learning with the 'Journal Writing' Technique.}

A set of questionnaires was given to students as a sample of this research to answer research question number 3, which is about students' attitudes towards learning Writing Skills using Journal Writing technique. Before being used, the questionnaire was first tested in a class that was not selected as a sample, namely class B. From the test results, it was found that one item number 5 was invalid, and the 'expert' suggested that item no 5 is discarded. After item no 5 was discarded, Cronbach's Alpha score (8.02) was obtained for a questionnaire about students' attitudes towards learning with the 'Journal Writing' technique in learning Writing Skills. This indicates that the questionnaire is valid and can be used in the sample class. Furthermore, a questionnaire about students' attitudes towards the Journal Writing technique employed in the class was given to the sample to be filled in accordance with their conditions and experiences when learning writing skills.

From the data presented in table 6, almost $64 \%$ of students have 'high' attitude towards learning writing skills using the Journal Writing technique. Only $1.22 \%$ of students have low attitude, while the rest $(35.12 \%)$ have moderate attitude. Thus, it can be said that almost $2 / 3$ students have high attitude towards learning Writing by applying Journal Writing technique.

Table 7. Students' $\begin{gathered}\text { Attitudes towards Journal Writing Techniques } \\
\text { in Learning Writing skills }\end{gathered}$
\begin{tabular}{cccc}
\hline \multicolumn{4}{c}{ Level } \\
\hline$>37$ & $\leq 50$ & High & \% \\
$>23 \leq 37$ & Moderate & 35.66 \\
$10 \leq 23$ & Low & 1.22 \\
\hline
\end{tabular}

The results of this study (1) the ability of students to write paragraphs is at the Good to Excellent level, are in accordance with the outcome of the study (2) the techniques 
of Journal Writing have a significant influence on students' ability to write paragraphs. The results of research (1) and (2) are also in accordance with the results of research (3) where almost $2 / 3$ of students have a 'high' attitude towards learning writing skills using the Journal Writing technique. However, further research is still needed to ensure the consistency of the data obtained from students' responses to the questionnaire. Thus, the three research questions about the effect of learning Writing Skills with the Journal Writing technique on the students' writing skills have been answered

\section{DISCUSSION}

The finding of this study where journal writing techniques possesses a significant influence on students' writing ability, provides more evidence concerning aforementioned researches about the influence of journal writing. Iliyanti (2009) used journal writing in her research and the students' writing ability improved significantly after the treatment. The research was conducted to English Education Department students of semester 4. In line with this, Wafa, Syafei and Riyono (2010) found that most of the students' writings were improved after having treatment using journal writing. This might be caused by their freedom to state their minds. Moreover, keeping journal writing also increases the potential of thoughts which possess big influence on their vocabulary development. They further claim that this technique is the perfect way for starting writing activities because it promotes students' creativity.

Furthermore, Peyton (2000) also found that (dialogue) journal writing facilitates lecturers recognize their students as their time together is prolonged. Liao and Wong's study (2001) discovered that (dialogue) journal writing increased all aspects of students' writing as well as their intrinsic writing motivation. Moreover, Barjesteh, Vaseghi and Gholami' study (2011) presented that diary writing (one technique of journal writing) is a dynamic prewriting stage in the class. The students are able to use their mind completely. In a consequence, journal writing is a significant feature of interaction with all people.

In line with the finding of this research where students have high attitude towards journal writing technique applied in their classroom, Barjesteh, Vaseghi and Gholami' study (2011) also found that students have good attitudes towards journal writing technique applied. 


\section{CONCLUSIONS}

The students' writing ability is at the Good to Excellent level. Only $43.24 \%$ of students are at the Average to Good level. Furthermore, Journal writing technique produces/causes higher writing achievement. This can be seen from the results of the t-test where the t-obs (8.26) is much greater than the t-value in the table (2.030). The students have 'high' attitude towards learning with the Journal Writing technique in the Writing Skills I. This result is in line with students' writing ability which is at the Good to Excellent level and the Journal Writing technique has a significant impact on students' writing skills. It can be further suggested from the results that journal writing technique can be used as a choice in teaching writing skills at university levels.

\section{REFERENCES}

Alexander, R. (2005). Culture, Dialogue and Learning: 10th International Conference International Association for Cognitive Education and Psychology (IACEP). University of Durham: UK.

Al-Khasawneh, Fadi Maher Saleh. (2009). Writing for Academic Purposes: Problems Faced by Arab Postgraduate Students of the College of Business. UUM. Retrieved from: http://www.esp-world.info/articles_28/writing.pdf.

Bagheri, Somayeh and Pourgharib, Behzad. (2013). An Investigation of the Effect of Journal Writing on EFL Learners' Oral Production. International Research Journal of Applied and Basic Sciences, 4(11).

Barjesteh B, Vaseghi R, Gholami R. (2011). The Effect of Diary Writing on EFL College Students' Writing Improvement and Attitudes. International Conference on Languages, Literature and Linguistics. Singapore: IACSIT Press.

Boud, D. (2001). Journal: Using Journal Writing to Enhance the Reflective Practice”. New Directions in Adult and Continuuing Education. San Francisco: Jossey-Bass.

Fitzpatrick, M. (2005). Engaging Writing: Paragraphs and Essays. New York: Longman

Badger, R and White, G. (2000). A Process Genre Approach to Teaching Writing. ELT Journal, 54(2), 153-160. Oxford: Oxford University Press, Academic Division.

Crosby, H.H and Carter, D.A. (1986). The Committed Writer: Mastering Nonfiction Genres. Caledonia: University Graphics, Inc. (ECU). 
Eliwarti, Eliwarti and Rumiri Aruan. (2018). A Survey on the Teaching of Writing at Senior High Schools in Riau Province. International Journal of Educational Best Practices (IJEBP), 2(2). Pekanbaru: University of Riau.

Ghaith, G. (2002). Writing. Retrieved from: American University of Beirut. http://www.nadasisland.com/ghaith-writing.html\#approaches.

Hatch, Ev and Lazaraton, A. (1990). The Research Manual. Design and Statistics for Applied Linguistics. Boston, Massachussette: Heine \& Heine Publishers.

Hiemstra, R. (2001). Uses and benefits of journal writing. In L. M. English \& M. A. Gillen, (Eds.), Promoting journal writing in adult education. New Directions for Adult and Continuing Education, 90, 19-26. San Francisco: Jossey-Bass.

Hyland, K. (2008). Second Language Writing. USA: Cambridge University Press.

Iliyanti, Novi. (2009). The Writing Ability of the Fourth Semester Students of English Education Department Teacher Training and Education Muria Kudus University in Academic Year 2008/2009 Taught by Using Journal Writing: A Heuristic Activity. Kudus: University of Muria Kudus.

Krashen, S.D. (1998). Second Language Acquisition and Second Language Learning. Prentice-Hall International.

Leki, I. (1996). Academic Writing: Esploring Processes and Strategies. New York: St. Martin's Press.

Lester, J.D. (1987). Writing Research Papers: A Complete Guide. Illinois, USA: Scott, Foresman and Company.

Lewis, B. (2009). Journal Writing in the Elementary Classroom; Offer Your Students an Organized and Inspired Journal Writing Program. Retrieved from: http://k6educators.about.com/cs/languageartswr/a/journalwriting.html

Lio MT, W.CT. (2007). Effect of Journals on L2 Students Writing Fluency, Reflexion, Anxiety and Motivation. Reflection of English Teaching, 9(2), 139-170. Tiwan: National Kaosiung Normal University.

McDoniel, M. (2008). Process Approach to Writing. Retrieved from: http://voices, yahoo.com/process-approach-writing-2101022.html.

Murcia, et. al. (2000). Discourse and Context in Language Teaching. New York: Cambridge University Press.

Oshima, A. and Hogue, A. (1999). Writing Academic English. New York: Addison Wesley Longman.

DOI: DOI: 10.32851/ijebp.v5n2.p183-196 
Patridge, B. (2004). Approaches to Teaching Second Language Writing. 17th Educational Conference Adelaide 2004. The University of Sydney.

Peyton, JK. (1993). Dialogue Journals: Interactive Writing to Develop Language and Literacy. ERIC Digest. Washington, DC: ERIC Clearinghouse on Languages and Linguistics. (EDRS No.ED 354 789).

Progoff, Ira. (1997). At a Journal Workshop. New York: Dialogue House Library.

Rao Z. (2007). Training in Brainstorming and Developing Writing Skills. ELT Journal 200, 61(2). Oxford: Oxford University Press.

Richards, J. (1990). New Trends in the Teaching of Writing in ESL/ EFL.

Wang Z. (ed.). ELT in China: Papers Presented at the International Symposium on Teaching English in the Chinese Context. Beijing: Foreign Language Teaching and Research Press,.

Saraka. (1988). From Paragraph to Essay: Concepts and Practices. Jakarta: Depdikbud, Dirjen Dikti: Proyek Pengembangan Lembaga Pendidikan Tenaga Kependidikan.

Syameducation. (2011). Collaborative Writing: Strategy Pengajaran Menulis dengan menggunakan Pendekatan Proses. Retrieved from: http://syamedu.blogspot.com/2011/03/collaborative-writing-strategy.html. Retrieved on April 17

Tarigan, H (2008). Menulis Sebagai Suatu Ketrampilan Bahasa. Bandung: Penerbit Angkasa.

Tribble, C. (2009). Writing. New York: Oxford University Press.

Ur, Penny. (1996). A Course in Language Teaching. Practice and Theory. Cambridge: Cambridge University Press.

Wafa, Asmal; Syafei, Muh and Riyono, Ahdi. (2010). Keeping Journal Writing to Improve the Writing Ability of the Tenth Grade Students of SMAN 1 Jekulo Kudus in the Academic Year 2009/2010.

Wiratno, Tri. (2003). Kiat Menulis Karya Ilmiah dalam Bahasa Inggris. Yogyakarta: Pustaka Pelajar. 